\title{
Marketing Opportunities for Blood Ark Clams and Ponderous Ark Clams ${ }^{1}$
}

\author{
Robert L. Degner, Tiffany B. Southwell, Leslie N. Sturmer, and Kimberly L. Morgan²
}

Significant growth in Florida's hard clam industry has motivated aquaculturists to explore alternative clam species to reduce potential production risks and to augment market expansion. Diversity of species could also provide some degree of protection against catastrophic losses.

Two alternative clam species with commercial potential are the Blood Ark (Anadara ovalis) and the Ponderous Ark (Noetia ponderosa). In the United States, wild stocks of Blood Arks range from Massachusetts to Texas. They are also found in the Caribbean and along the coast of Brazil. The Ponderous Ark is found from Virginia to Texas. Wild stocks of the Blood Ark and Ponderous Ark clams are currently harvested in North Carolina and Virginia in limited quantities for ethnic markets in the United States.

The development of a major fishery for these species has been limited by a variety of factors, including dispersed wild clam populations; minimal understanding of clam reproduction; and relatively small, isolated ethnic markets. Until recently, these clams have been largely overlooked by the shellfish and fishing industries.

The basic objective of this study was to determine the present market potential of Blood Ark and Ponderous Ark clams in the United States. This paper summarizes research that attempted to quantify the shellfish trade industry's present awareness and acceptance of the Blood Ark and Ponderous Ark clams as a first step in evaluating the economic feasibility of producing these clams in commercial quantities using commercially feasible aquacultural production techniques by the existing hard clam industry.

This study was conducted in three phases. Phase I was a nationwide census of all shellfish dealers certified by the Food and Drug Administration. Questionnaires were mailed to 2,133 firms to determine the current market situation for the two selected species of clams. In Phase II, firms responding to the initial survey that had expressed interest in possibly selling the two species of clams were sent live samples for evaluation. Phase III determined shelf life (life expectancy under typical

1. This is EDIS document FE478, a publication of the Department of Food and Resource Economics, Florida Cooperative Extension Service, UF/IFAS, University of Florida, Gainesville, FL. Published August 2005. Please visit the EDIS website at http://edis.ifas.ufl.edu.

2. Robert L. Degner, Professor, Department of Food and Resource Economics, University of Florida; Tiffany B. Southwell, former graduate student, Department of Food and Resource Economics, University of Florida; Leslie N. Sturmer, Levy County Extension Agent, Cedar Key, FL; and Kimberly L. Morgan, Coordinator of Economic Analysis, Department of Food and Resource Economics, Florida Cooperative Extension Service, UF/IFAS, University of Florida, Gainesville, FL.

The Institute of Food and Agricultural Sciences (IFAS) is an Equal Opportunity Institution authorized to provide research, educational information and other services only to individuals and institutions that function with non-discrimination with respect to race, creed, color, religion, age, disability, sex, sexual orientation, marital status, national origin, political opinions or affiliations. U.S. Department of Agriculture, Cooperative Extension Service, University of Florida, IFAS, Florida A. \& M. University Cooperative Extension Program, and Boards of County Commissioners Cooperating. Larry Arrington, Dean 
commerical refrigeration) and nutritional composition. Results of Phase III are reported in IR-05-1, published by the Florida Agricultural Market Research Center

(http://www.agmarketing.ifas.ufl.edu) and summarized in EDIS publication FE568 (http://edis.ifas.ufl.edu/FE568).

In Phase I, about 92 percent of the responding shellfish firms had no experience with Blood Ark clams. Only one percent of respondent firms sold Blood Ark clams during 2001. Among certified shellfish shippers that responded to the questionnaire, over 90 percent had no experience with Ponderous Ark clams. Less than two percent had seen them at trade shows, and only one percent had sold them in the past. With only one respondent currently selling Ponderous Arks, market exposure is presently extremely limited. It appears that the current market for the Blood Ark and Ponderous Ark clams is extremely limited due to lack of consistent supplies, limited market outlets, and virtually nonexistent consumer demand.

On a positive note, some shellfish shippers indicated an interest in learning more about these clam types. Out of 309 respondents, 97 provided mailing address information and requested Blood Ark clam samples, and 96 gave contact information to receive Ponderous Ark clam samples. However, when samples became available, only 83 firms agreed to accept and evaluate them.

In Phase II, 83 firms received live samples of the two types of clams. They were asked to evaluate a number of basic product characteristics, including appearance, taste, aroma, and textural properties. These respondents were also asked to estimate potential sales through their respective firms.

Samples of the two types of clams were harvested from approved waters in mid-November of 2003, and were held overnight in a refrigerated facility owned by a certified shellfish dealer in Cedar Key, Florida. Approximately eight clams of each type were placed in separate small, color-coded plastic mesh bags with official shipper tags affixed to each bag. The two bags of clams were placed in an insulated shipping container along with refrigerated gel packs, evaluation instructions, and a one-page questionnaire for each type of clams. The samples were shipped via a major courier service within several hours of packaging, and were delivered to all recipients before noon the next day.

Nearly one-half of the 83 samples were sent to firms in the Northeast, and nearly one-third went to firms in the South. Only two firms in the Midwest agreed to evaluate samples; both were in the Chicago area. Approximately one-fifth of the samples were shipped to firms on the West coast. Despite the care and diligence exercised in gaining the cooperation of the shellfish dealers receiving samples, only 52 of the 83 provided completed product evaluations, even after several follow-up telephone calls.

The majority of the sample recipients indicated that the samples arrived in excellent condition. However, several said their samples were slightly too warm for optimum shellfish storage conditions. Respondents were asked whether or not they could detect an odor from the samples. Sixty percent said they could not detect an odor. Of those who said they could detect an odor, only a small minority described the odor as "slightly unpleasant."

Respondents were asked to rate the appearance of the shells using a zero-to-ten rating scale where zero represented "very unattractive" and ten represented "very attractive." Both species of clams received mediocre evaluations, with average ratings of approximately five. Respondents were also to comment on appearance; critics complained of the black color and "fuzzy" or "furry" appearance. There was concern that cleaning would be time consuming and costly. There were very few positive comments about the clams' appearance.

Meat color was evaluated using the same zero-to-ten rating scale. The attractiveness ratings for meat color fared worse than those for shell appearance, with average ratings of 4.2 for Blood Arks and 3.6 for Ponderous Arks. A paired t-test indicated that the meat color rating differences between the two species were statistically significant. As the mean ratings suggest, meat color evaluations were heavily skewed towards the "very unattractive" end of the rating scale; nearly 15 percent of the respondents gave a zero rating to meat color of Blood Arks, and 22 percent gave a zero rating 
to meat color of Ponderous Arks. Most comments made with respect to meat color were negative, criticizing the bloody appearance, but some were positive, stating the clam meat was "colorful" and "normal after cooking."

Respondents rated "taste" using a similar scale of zero to ten, where zero represented "very poor" and ten represented "extremely good."

Respondents were asked to rate taste if eaten raw or if eaten cooked. Mean ratings were just under five for taste if eaten raw, and approximately five if eaten cooked. Taste ratings for whether eaten raw or eaten cooked were not statistically different for the two types of clams.

Texture was evaluated using a five-point semantic differential scale ranging from "much too tough" to "much too soft," with the mid-point being "just right." Respondents said that both types of clams were "slightly" or "much too tough" (55 percent for Blood Arks and 60 percent for Ponderous Arks). Texture differences were not statistically significant for the two species of clams.

When questioned about the number of clams of each type they could sell per week, just over one-half of the dealers said they could not sell any of the Blood Arks. About one-fifth of all respondents would not project sales, stating that they simply did not know how many, if any, they could sell. Eleven firms made positive sales projections, but these estimates were extremely variable, ranging from 30 to 170,000 clams per week.

Sixty percent of the respondents felt they could not sell any Ponderous Ark clams. About one-fifth said they did not know how many they could sell. Only eight firms provided weekly sales estimates; their responses ranged from 30 to 120,000 clams.

When asked for general comments about the clam samples, numerous respondents said they had trouble cooking them. Comments were similar for both types of clams. Many said it took too long for them to cook; some said they never opened and others said they were difficult to open. Respondents also mentioned marketability issues. Although many of the comments were negative, some were positive. Most of the positive comments reflected the opinion that both types of clams would appeal to ethnic markets, primarily Asian consumers.

In summary, the current market for both Blood Ark and Ponderous Ark clams is very limited in the United States. There is widespread lack of familiarity with these species, and very few shellfish dealers, probably less than one percent, are currently selling them.

As to the potential marketability of these species, the product evaluations and many of the respondents' comments indicate that these two species of clams are perceived as being too different from clams currently available on the market. These findings, coupled with the low response rates and shellfish dealers' unwillingness to evaluate free samples, leads us to conclude that it is unlikely that there will be a widespread, mainstream demand for them.

Despite the overall pessimistic tone of these findings, market development proponents should recognize the importance of ethnic markets in target locations on both the East and West coasts. Targeting seafood dealers in these areas with large Asian and Hispanic populations could result in profitable niche markets.

Additionally, producer groups should work with the Aquaculture Division of the Florida Department of Agriculture and Consumer Services (FDACS) to provide information about Blood Ark and Ponderous Ark clams to potential dealers at national seafood trade shows. Such information could also be incorporated into the FDACS website to foster greater knowledge in the trade and to arouse dealers' curiosity. These promotional methods could serve as relatively inexpensive promotional tools.

The complete report can be found on the website of the Florida Agricultural Market Research Center under "Publications", Market Research Publications, 2000-present (Marketing Opportunties for Two Ark Clam Species). The online address is http://www.agmarketing.ifas.ufl.edu. 